\title{
Iron-based ferritin nanocore as a contrast agent ${ }^{\mathrm{a})}$
}

\author{
Barindra Sana \\ Division of Bioengineering, School of Chemical and Biomedical Engineering, Nanyang Technological \\ University, Singapore 637457 \\ Eric Johnson \\ Howard Hughes Medical Institute, Division of Chemistry and Chemical Engineering, California Institute \\ of Technology, Pasadena, California 91125
}

Kenneth Sheah

Radlink Diagnostic Imaging, Paragon Medical, Singapore 238859

Chueh Loo Poh ${ }^{\text {b) }}$ and Sierin Lim ${ }^{\text {b) }}$

Division of Bioengineering, School of Chemical and Biomedical Engineering, Nanyang Technological University, Singapore 637457

(Received 17 May 2010; accepted 3 August 2010; published 14 December 2010)

\begin{abstract}
Self-assembling protein cages have been exploited as templates for nanoparticle synthesis. The ferritin molecule, a protein cage present in most living systems, stores excess soluble ferrous iron in the form of an insoluble ferric complex within its cavity. Magnetic nanocores formed by loading excess iron within an engineered ferritin from Archaeoglobus fulgidus (AfFtn-AA) were studied as a potential magnetic resonance (MR) imaging contrast agent. The self-assembly characteristics of the AfFtn-AA were investigated using dynamic light scattering technique and size exclusion chromatography. Homogeneous size distribution of the assembled nanoparticles was observed using transmission electron microscopy. The magnetic properties of iron-loaded AfFtn-AA were studied using vibrating sample magnetometry. Images obtained from a 3.0 T whole-body MRI scanner showed significant brightening of $T_{1}$ images and signal loss of $T_{2}$ images with increased concentrations of iron-loaded AfFtn-AA. The analysis of the MR image intensities showed extremely high $\mathrm{R}_{2}$ values $\left(5300 \mathrm{mM}^{-1} \mathrm{~s}^{-1}\right)$ for the iron-loaded AfFtn-AA confirming its potential as a $\mathrm{T}_{2}$ contrast agent. (C) 2010 American Vacuum Society. [DOI: 10.1116/1.3483216]
\end{abstract}

\section{INTRODUCTION}

Magnetic resonance imaging (MRI) is a medical imaging technique used to visualize the detailed internal structure of parts of the human body. Contrast differences between soft tissues observed in MR images can be used to diagnose diseased tissues. Contrast agents are often used to enhance contrast between soft tissues. For example, during the staging of liver cancer using MRI, contrast agents are routinely used to improve the contrast between liver lesions and the surrounding tissues, which facilitate lesion detection. ${ }^{1}$ However, commercially available MRI contrast agents are limited in its ability to monitor small tissue lesions, and molecular or cellular activities. ${ }^{2}$ The search for ultrasensitive contrast agents has become central in MRI research. Beside other metal complexes, magnetic nanoparticles attract special attention due to significantly higher relaxivity than those of available gadolinium-based complexes. ${ }^{3-5}$ Several nanocarriers, such as liposomes and microbubbles, have been investigated to determine their ability to deliver higher amounts of contrast agent. ${ }^{6-8}$ For in vivo application, these carrier molecules and

\footnotetext{
a) This paper is part of an In Focus section on Biointerphase Science in Singapore, sponsored by Brukner Optik Southeast Asia, IMRE, the Provost's Office and School of Materials Science and Engineering of Nanyang Technological University, and Analytical Technologies Pte Ltd.

${ }^{b)}$ Authors to whom correspondence should be addressed; electronic addresses: slim@ntu.edu.sg and clpoh@ntu.edu.sg
}

their metabolic products should be biocompatible and stable within physiological system. ${ }^{9}$ Here we examine a modified ferritin as a template for synthesizing magnetic nanocore and the potential application of this metal-protein composite as a MRI contrast agent. One advantage of utilizing these proteinaceous carriers stems from the protein-associated water molecules that can contribute to the enhancement of nuclear relaxation rates. ${ }^{10}$ In addition, the nanoparticles synthesized within ferritin cages have a narrow range of particle size distribution when compared to chemically synthesized nanoparticles. ${ }^{11}$

Ferritins are iron storage proteins found in most living systems; they form roughly spherical cage-like structures with an internal cavity $(\sim 8 \mathrm{~nm}$ diameter) that can be loaded with a large number of small molecules. ${ }^{12-14}$ Ferritins convert soluble ferrous salts to a ferric complex, and the latter is stored within the internal cavity as magnetic nanocores. ${ }^{15,16}$ $\mathrm{T}_{2}$ contrast enhancements by endogenous ferritin were used to estimate iron deposition in liver, pancreas, and spleen in healthy or diseased states. ${ }^{17-21}$ The surface of the ferritin molecule can be chemically/genetically modified to impart novel functionalities including tissue targeting by conjugating with receptor specific functional groups. ${ }^{13,22,23}$ Ferritin encapsulated gadolinium-based contrast agents have also been reported to have improved $\mathrm{R}_{1}$ relaxivity compared to 


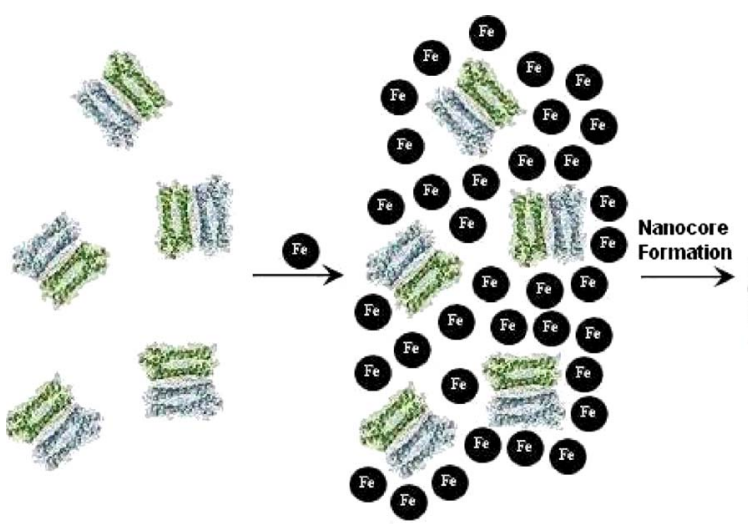

(A)
(B)

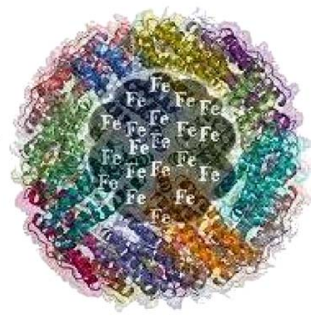

(C)

FIG. 1. (Color online) Schematic presentation of self-assembly of AfFtn dimers and nanocore formation upon addition of $\mathrm{Fe}^{2+}$. AfFtn is observed primarily as a dimeric species in solutions of low ionic strength and in the absence of divalent metal ions (a). Upon addition of divalent metal ions (b), AfFtn subunits form a 24-meric protein cage (c). Similar self-assembly conditions are observed for AfFtn-AA.

the free gadolinium complexes. ${ }^{5,10}$ On the other hand, human ferritin iron oxide nanocomposites show relatively low $\mathrm{R}_{1}$ and $\mathrm{R}_{2}$ values. ${ }^{12}$

In the present study, significantly higher $\mathrm{R}_{1}$ and $\mathrm{R}_{2}$ relaxivities were achieved by synthesizing iron based magnetic nanocores within the cavity of an engineered Archaeoglobus fulgidus ferritin. The protein cage of wild type A. fulgidus ferritin (AfFtn) contains four large pores making it unique among any ferritin of known structure reported to date. ${ }^{24} \mathrm{In}$ solutions of low ionic strength, the apo-AfFtn exists as dimeric species. Increased ionic strength or addition of divalent metal ions leads to the self-assembly of these dimers into a spherical cage comprised of 24 subunits. In this study, the lysine 150 and arginine 151 of AfFtn were replaced by alanine to modulate the four large pores and the mutant is referred to as AfFtn-AA. This mutant assembles into cagelike structure (24-mer) at lower ionic strength compared to AfFtn. Encapsulation of metal ions within the AfFtn-AA cavity facilitates formation of a metallic nanocore (Fig. 1). Longitudinal and transverse relaxivities $\left(\mathrm{R}_{1}\right.$ and $\left.\mathrm{R}_{2}\right)$ of the nanocomposite were studied to evaluate its potential as a MRI contrast agent. The $R_{1}$ and $R_{2}$ values of the samples are significantly higher compared to those of reported MRI contrast agents, thus indicating a new means to enhance $R_{2}$ relaxivity by using this metal-protein nanocomposite.

\section{MATERIALS AND METHODS}

\section{A. Ferritin}

Cloning, expression, and purification of the engineered $A$. fulgidus ferritin were carried out following previously described method. ${ }^{24}$ Briefly, the A. fulgidus ferritin gene (AF0834) was cloned into a pET-11a vector and the protein was genetically engineered by site directed mutagenesis to alter the amino acids at positions 150 and 151 to alanines (AfFtn-AA). The plasmid was a generous gift from Professor Imke Schröder at UCLA. The AfFtn-AA was produced in $E$. coli BL21(DE3) CodonPlus-RIL cells (Stratagene, Santa Clara, CA). AfFtn-AA was purified to homogeneity by heat treatment $\left(90{ }^{\circ} \mathrm{C}\right.$ for $\left.10 \mathrm{~min}\right)$ of cleared cell lysates followed by hydrophobic interaction chromatography. The purified protein was stored in $25 \mathrm{mM}$ HEPES with $50 \mathrm{mM} \mathrm{NaCl}(\mathrm{pH}$ 7.5) at $4{ }^{\circ} \mathrm{C}$.

\section{B. Nanocore formation}

Iron-based magnetic nanocores were formed following the method described by Liu et al. ${ }^{25}$ Freshly prepared ferrous sulfate solution in $0.1 \% \mathrm{HCl}$ was slowly added to solutions of dimeric apo-AfFtn-AA and incubated for $1 \mathrm{~h}$ at room temperature $\left(23{ }^{\circ} \mathrm{C}\right)$ and followed by overnight incubation at $4{ }^{\circ} \mathrm{C}$. The iron loading was carried out by adding up to 15 $\mathrm{mM} \mathrm{Fe}^{2+}$ to $2.08 \mu \mathrm{M}$ AfFtn-AA in $100 \mathrm{mM}$ HEPES buffer $(\mathrm{pH} 7.0)$ containing $50 \mathrm{mM} \mathrm{NaCl}$. Unbound iron was removed by buffer exchange using an Amicon centrifugal filter device (100 kD MWCO; Millipore, Billerica, MA). Following iron loading and buffer exchange, the encapsulated iron content of the protein was determined by conversion of the encapsulated ferric complex to the ferrous form and quantification with bathophenanthroline disulfonic acid, disodium salt hydrate at $538 \mathrm{~nm}$, as previously described by Bonomi et $a l .^{26}$ with slight modification. The stoichiometric loading amount was calculated to be $\sim 7200 \mathrm{Fe} / 24$-mer.

\section{Characterization of iron-loaded AfFtn-AA}

Iron-mediated self-assembly of AfFtn-AA subunits was studied by monitoring the change of hydrodynamic diameter upon metal binding using a Zetasizer Nano ZS dynamic light scattering (DLS) instrument (Malvern Instruments, Worcestershire, UK) at $25{ }^{\circ} \mathrm{C}$ with 5 min equilibration. The molecular size of apo-AfFtn-AA and iron-loaded AfFtn-AA were confirmed through size exclusion chromatography (SEC) using a Superdex 200 10/300 GL column (GE Healthcare, Buckinghamshire, UK).

TEM was used to verify the self-assembly and to confirm the dimension of iron-loaded AfFtn-AA molecules. Carboncoated parlodion support films mounted on copper grids were made hydrophilic immediately before use by high- 
voltage, alternating current glow-discharge. Samples of ironloaded AfFtn-AA $(0.5 \mathrm{mg} / \mathrm{ml} ; 4800 \mathrm{Fe} / 24-\mathrm{mer})$ were applied directly onto grids and allowed to adsorb for $30 \mathrm{~s}$. Grids were rinsed with 2 drops of double distilled water and stained with $1 \%$ uranyl acetate for $30 \mathrm{~s}$. Specimens were examined in a T12 electron microscope (FEI Tecnai, Hillsboro, OR) at an accelerating voltage of $120 \mathrm{kV}$.

For magnetic characterization, an aliquot of the ironloaded AfFtn-AA (4800 Fe/24-mer) was buffer exchanged with water and lyophilized. The lyophilized iron-loaded AfFtn-AA was characterized in a $1.5 \mathrm{~T} 7300$ series vibrating sample magnetometer (Lakeshore, Westerville, $\mathrm{OH}$ ) under a magnetic field strength of up to $1.2 \mathrm{~T}$ at room temperature.

\section{MR imaging and relaxivity measurement}

MRI samples of iron-loaded AfFtn-AA ( 7000 Fe/24mer) were prepared with protein concentrations ranging from 0.05 to $1.0 \mu \mathrm{M}$ embedded in a $0.8 \%$ agarose matrix in $24-$ well tissue culture plates. MR imaging was performed and MR relaxivities of the samples were calculated to evaluate its potential as a MRI contrast agent. All samples were imaged in a $3.0 \mathrm{~T}$ whole-body scanner (GE Healthcare, Waukesha, WI) using a dedicated knee coil. For the measurement of longitudinal relaxation times $\left(\mathrm{T}_{1}\right)$, an inversion recovery spin-echo sequence was used (repetition time $T_{R}=2200 \mathrm{~ms}$; echo time $\mathrm{T}_{\mathrm{E}}=9 \mathrm{~ms}$; inversion time $\mathrm{T}_{\mathrm{I}}$ $=450,500,600,920,800,2000 \mathrm{~ms}$, matrix $=512 \times 512$, slice thickness $=6.0 \mathrm{~mm}, \mathrm{NEX}=1$, and field of view $=23 \mathrm{~cm}$ ). For the measurement of transverse relaxation times $\left(\mathrm{T}_{2}\right)$, a spin-echo sequence with different echo times was used $\left(T_{R}\right.$ $=1960 \mathrm{~ms} \mathrm{~T}_{\mathrm{E}}=10,15,20,40,80,120,180,400 \mathrm{~ms}$, matrix $=512 \times 512$, slice thickness $=6.0 \mathrm{~mm}, \mathrm{NEX}=1$, and field of view $=23 \mathrm{~cm}$ ). The $T_{1}$ and $T_{2}$ values for each sample were calculated from mean signal intensity of MR images by using MATLAB (The Mathworks, Natick, MA). For the calculation of $T_{1}$ values, a nonlinear fit of the intensity data $\left(T_{1}\right.$ weighted images) to the inversion-recovery signal equation was performed by using cftool-fitting in customized equation. The $T_{2}$ of each sample was calculated by fitting the intensities of $T_{2}$ weighted images to a monoexponential decay curve using the same method. Relaxivities $\left(R_{1}\right.$ and $\left.R_{2}\right)$ of each sample was derived from the $T_{1}$ and $T_{2}$ values at varying protein concentrations. Gradients of the linear fit obtained by plotting inverse relaxation times $\left(1 / \mathrm{T}_{1}\right.$ and $\left.1 / \mathrm{T}_{2}\right)$ against AfFtn-AA concentrations indicate $R_{1}$ and $R_{2}$ relaxivities, respectively. Images were also acquired using a gradient echo sequence $\left(\mathrm{T}_{\mathrm{R}}=500 \mathrm{~ms}, \mathrm{~T}_{\mathrm{E}}=6.7 \mathrm{~ms}\right.$, matrix 512 $\times 512$, slice thickness $=4.0 \mathrm{~mm}, \mathrm{NEX}=1$, and field of view $=23 \mathrm{~cm}$ ) to assess the relative visual signal at $3.0 \mathrm{~T}$.

\section{RESULTS AND DISCUSSION}

\section{A. Characterization of iron-loaded AfFtn-AA}

Mineralization of dimeric apo-AfFtn-AA with $\mathrm{Fe}^{2+}$ results in the self-assembly of 24 subunits and the formation of an iron-protein conjugate. DLS data confirm the self-assembly of AfFtn-AA subunits. The shift in hydrodynamic diameter

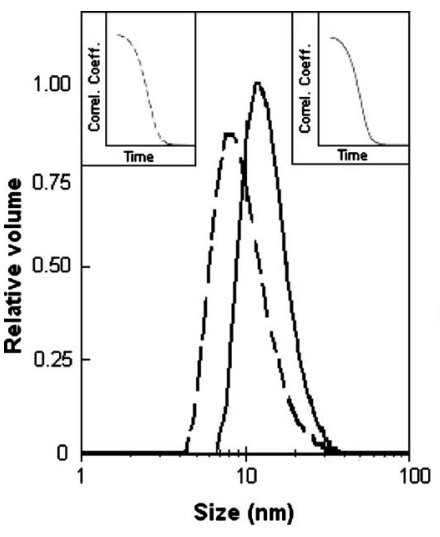

(A)

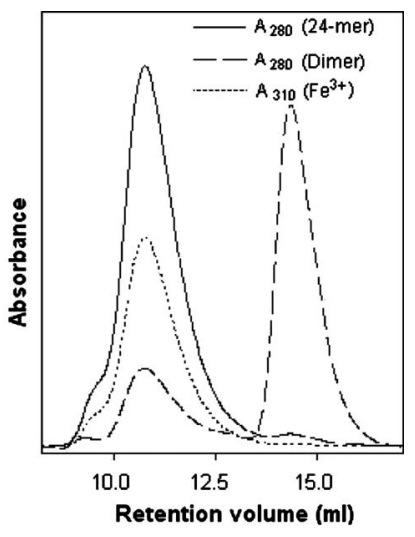

(B)
FIG. 2. Size determination of apo-AfFtn-AA (dashed) and assembled 24-mer AfFtn-AA (solid) as measured by hydrodynamic diameter in DLS (a) and retention volume in SEC (b). Correlograms are shown in (a) (inset). The presence of $310 \mathrm{~nm}$ peak at $\sim 11 \mathrm{ml}$ indicates coelution of $\mathrm{Fe}^{3+}$ (dotted) and the 24-mer AfFtn-AA, as shown in Fig. 2(b).

from $9.5 \pm 0.9$ to $14.5 \pm 1.0 \mathrm{~nm}$ corresponds to dimeric species in the absence and fully assembled 24-mer in the presence of iron, respectively [Fig. 2(a)]. Assembly of the 24mer and the mineralization of the AfFtn-AA is further confirmed using SEC. The observation of a peak at $310 \mathrm{~nm}$ indicates coelution of ferric iron $^{27,28}$ with the assembled AfFtn-AA 24-mer and demonstrates formation of the metalprotein composite [Fig. 2(b)]. Almost 100\% of the AfFtn-AA subunits are assembled into 24-mers in the presence of iron, while the $\sim 20 \%$ that form 24-mer in the absence of iron are due to the presence of sodium chloride in the buffer solution. Salt-mediated assembly has been previously observed in the AfFtn. ${ }^{24}$ Quantification of iron content shows that $>7000 \mathrm{Fe}$ atoms can be encapsulated per 24-meric AfFtn-AA (data not shown). Lower iron loading (4800 Fe/24-mer) also results in the formation of a cage-like structure as revealed in the transmission electron micrograph (Fig. 3).

The magnetic properties of iron-loaded AfFtn-AA were studied by VSM; the magnetization profile is presented in the hysteresis loop (Fig. 4). The curve has a similar shape to the hysteresis loop of iron-loaded ferritin from the archaeon $P y$ rococcus furiosus and engineered human $\mathrm{H}$-chain ferritin. ${ }^{13,29}$ The saturated magnetization (Ms) is 0.435 $\mathrm{emu} / \mathrm{g}$, where as retentivity $(\mathrm{Mr})$ and coercivity (Hci) of the composite are $0.052 \mathrm{emu} / \mathrm{g}$ and $224 \mathrm{G}$, respectively.

\section{B. MR imaging and relaxivity}

Intensities of the MR images obtained with various concentrations of iron-loaded AfFtn-AA were computed to obtain its relaxivity. Higher concentrations of iron-loaded AfFtn-AA enhance brightness of $\mathrm{T}_{1}$ images and signal loss of $T_{2}$ images [Fig. 5(a)]. The relative visual signal of MR images at $3.0 \mathrm{~T}$ demonstrates increased contrast at long TEs (data not shown). $\mathrm{T}_{1}$ and $\mathrm{T}_{2}$ values (calculated from the signal intensity) decrease sharply with increasing concentrations of iron-loaded AfFtn-AA. The gradients of the linear fits presented in Fig. 5(b) indicate the $R_{1}$ and $R_{2}$ relaxivities 


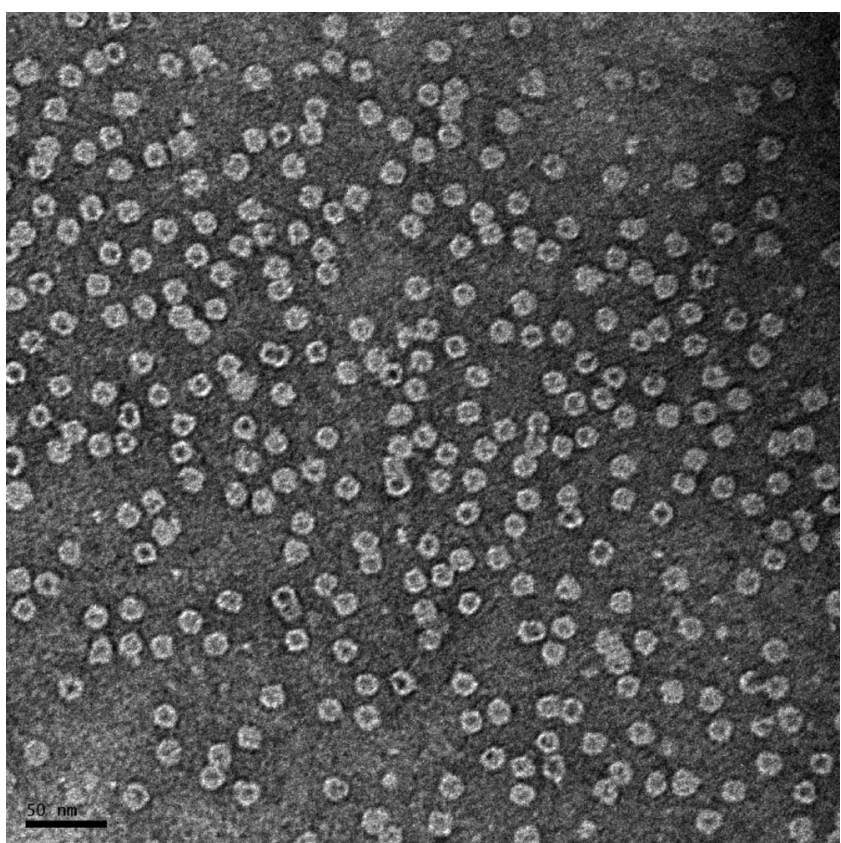

FIG. 3. Transmission electron micrograph of mineralized AfFtn-AA (4800 Fe/24-mer) stained with $1 \%$ uranyl acetate. Scale bar is $50 \mathrm{~nm}$.

of iron-loaded AfFtn-AA. The values of $\mathrm{R}_{1}$ and $\mathrm{R}_{2}$ relaxivities per iron-loaded AfFtn-AA reach 1200 and $5300 \mathrm{mM}^{-1} \mathrm{~s}^{-1}$, respectively, due to the presence of $>7000$ $\mathrm{Fe}$ atoms in the cavity. The relaxivities of iron-loaded AfFtn-AA are two orders of magnitude higher than previously reported $R_{1}$ and $R_{2}$ values $\left(8.4\right.$ and $93 \mathrm{mM}^{-1} \mathrm{~s}^{-1}$, respectively) of human ferritin iron oxide nanocomposites formed by encapsulating $5000 \mathrm{Fe}$ per cage. ${ }^{12}$ This observation suggests that the AfFtn-AA contributes to obtaining significantly higher relaxivities in a metal-protein conjugate when compared to human ferritin iron oxide nanocomposite. This may be explained by the ability to compartmentalize a relatively large number of iron atoms and diffusibility of associated water molecules through ferritin channels, as suggested by Aime et al. ${ }^{10}$

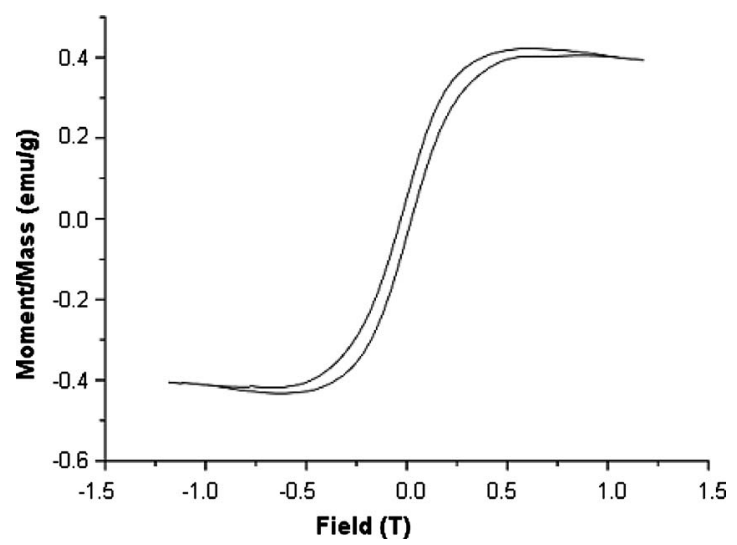

FIG. 4. Hysteresis loop (magnetization vs applied field) of iron-loaded AfFtn-AA

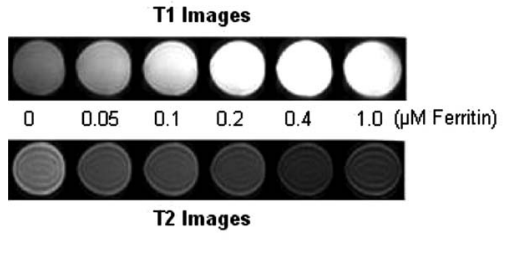

(A)

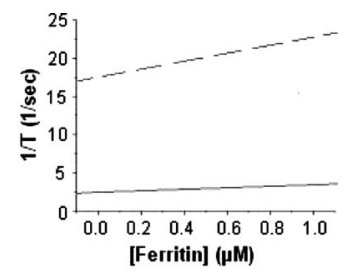

(B)
FIG. 5. (a) $\mathrm{T}_{1}$-and $\mathrm{T}_{2}$-weighted images of iron-loaded AfFtn-AA as contrast agent at different concentrations embedded in a $0.8 \%$ agarose matrix. (b) Graphical determination of longitudinal (solid) and transverse (dashed) relaxivity of iron-loaded AfFtn-AA.

The iron-loaded AfFtn-AA molecule also exhibits superior properties as a $T_{1}$ contrast agent relative to Gd-loaded ferritin molecules. ${ }^{10} \mathrm{R}_{1}$ values for each ferritin-bound $\mathrm{Gd}^{3+}$ complex were $80 \pm 5 \mathrm{mM}^{-1} \mathrm{~s}^{-1}$ under conditions where each ferritin contained about 10 molecules of the $\mathrm{Gd}^{3+}$ complex. In contrast, each AfFtn-AA nanocage is capable of encapsulating $>7000 \mathrm{Fe}$ atoms and a much higher $\mathrm{R}_{1}$ relaxivity is observed $\left(1200 \mathrm{mM}^{-1} \mathrm{~s}^{-1}\right)$. In addition, a high $\mathrm{R}_{2} / \mathrm{R}_{1}$ $(\sim 4.5)$ ratio and a significantly higher $R_{2}$ value are observed suggesting the AfFtn-AA nanocore is likely to be suitable as a $T_{2}$ contrast agent.

\section{CONCLUSION}

The characterization of the iron nanocore synthesized by encapsulation of $\mathrm{Fe}$ atoms within an AfFtn-AA cage confirmed its potential as a $T_{2}$ contrast agent for MR imaging. $R_{1}$ and $R_{2}$ values of iron-loaded AfFtn-AA were much higher than previously reported human ferritin iron oxide nanocomposites. The high iron loading capacity of the AfFtn-AA may contribute to the observation of the high relaxivity. Another factor that may also influence the relaxivities is diffusibility of water molecules through the AfFtn-AA channels. Further studies need to be conducted in order to better understand how nanocores within the engineered AfFtn-AA lead to such a dramatically increased relaxivity. When compared to the chemical synthesis of nanoparticles, utilization of a ferritin nanocage allows for precise size control and results in the synthesis of a highly uniform nanocore having homogeneous physical characteristics. In addition to serving as a template for controlled magnetic nanocore formation, the proteinaceous nature of ferritin molecules confers additional advantages including the possibility to incorporate functional groups, which are essential for tissue-specific localization. Furthermore, by conjugating drug molecules, the ferritin molecule may serve as a multimodal therapeutic agent that can simultaneously diagnose and treat diseased tissues.

\section{ACKNOWLEDGMENTS}

The authors wish to thank Alasdair W. McDowall for assistance with electron microscopy, Dhandie Cervantes, and Renuka for assistance with the MRI. A.W.M. and the EM center are supported by funding awarded through the Beck- 
man Institute Foundation. This work is funded by the Singapore Ministry of Education Academic Research Fund Tier I (Grant No. RG33/07).

${ }^{1}$ M. R. Oliva and S. Saini, Cancer Imaging 4, S42 (2004).

${ }^{2}$ J. Lu et al., Biomaterials 30, 2919 (2009).

${ }^{3}$ B. A. Moffat et al., Mol. Imaging 2, 324 (2003).

${ }^{4}$ S. Mornet, S. Vasseur, F. Grasset, and E. Daguet, J. Mater. Chem. 14, 2161 (2004).

${ }^{5}$ P. Sánchez, E. Valero, N. Galvez, J. M. Dominguez-Vera, M. Marinone, G. Poletti, M. Corti, and A. Lascialferi, Dalton Trans. 5, 800 (2009).

${ }^{6}$ S. L. Fossheim, A. K. Fahlvik, J. Klaveness, and R. N. Muller, Magn. Reson. Imaging 17, 83 (1999).

${ }^{7}$ G. J. Strijkers, W. J. M. Mulder, R. B. van Heeswijk, P. M. Frederick, P. Bomans, P. C. M. M. Magusin, and K. Nicolay, Magn. Reson. Mater. Phys., Biol., Med. 18, 186 (2005).

${ }^{8}$ F. Yang, Y. Li, Z. Chen, Y. Zhang, J. Wu, and N. Gu, Biomaterials 30, 3882 (2009).

${ }^{9}$ W. J. M. Mulder, G. J. Strijkers, G. A. F. van Tilborg, A. W. Griffioen, and K. Nicolay, NMR Biomed. 19, 142 (2006).

${ }^{10}$ S. Aime, L. Frullano, and S. G. Crich, Angew. Chem., Int. Ed. 41, 1017 (2002).

${ }^{11}$ H. Yoshimura, Colloids Surf., A 282-283, 464 (2006).

${ }^{12}$ M. Uchida et al., Magn. Reson. Med. 60, 1073 (2008).

${ }^{13}$ M. Uchida et al., J. Am. Chem. Soc. 128, 16626 (2006).
${ }^{14}$ E. Simsek and M. A. Kilic, J. Magn. Magn. Mater. 293, 509 (2005).

${ }^{15}$ N. D. Chasteen and P. M. Harrison, J. Struct. Biol. 126, 182 (1999).

${ }^{16} \mathrm{P}$. Harrison and P. Arosio, Biochim. Biophys. Acta 1275, 161 (1996).

${ }^{17}$ I. L. Angulo, D. T. Covas, A. A. Carneiro, O. Baffa, J. E. Junior, and G. Vilela, Revista Brasileira de Hematologia e Hemoterapia 30, 449 (2008).

${ }^{18}$ M.-J. Kim, D. G. Mitchell, K. Ito, H.-W. L. Hann, Y. N. Park, and P. N. Kim, Abdom. Imaging 26, 149 (2001).

${ }^{19}$ P. Mazza et al., Hematologica 80, 398 (1995).

${ }^{20}$ N. F. Schwenzer et al., Invest. Radiol. 43, 854 (2008).

${ }^{21}$ A. Taher, F. El Rassi, H. Isma'eel, S. Koussa, A. Inati, and M. D. Cappellini, Hematologica 93, 1584 (2008).

${ }^{22}$ I. Yamashita, H. Kirimura, M. Okuda, K. Nishio, K. I. Sano, K. Shiba, T. Hayashi, M. Hara, and Y. Mishima, Small 2, 1148 (2006).

${ }^{23}$ B. Zheng, I. Yamashita, M. Uenuma, K. Iwahori, M. Kobayashi, and Y. Uraoka, Nanotechnology 21, 045305 (2010).

${ }^{24}$ E. Johnson, D. Cascio, M. R. Sawaya, M. Gingery, and I. Schröder, Structure 13, 637 (2005).

${ }^{25}$ X. Liu, W. Jin, and E. C. Theil, Proc. Natl. Acad. Sci. U.S.A. 100, 3653 (2003).

${ }^{26}$ F. Bonomi and S. Pagani, Eur. J. Biochem. 155, 295 (1986).

${ }^{27}$ S. Levi, A. Luzzago, G. Cesareni, A. Cozzi, F. Franceschinelli, A. Albertini, and P. Arosio, J. Biol. Chem. 263, 18086 (1988).

${ }^{28}$ I. G. Macara, T. G. Hoy, and P. M. Harrison, Biochem. J. 126, 151 (1972).

${ }^{29}$ M. J. Parker, M. A. Allen, B. Ramsay, M. T. Klem, M. Young, and T. Douglas, Chem. Mater. 20, 1541 (2008). 